\title{
Bevordering van interculturele competentie in het universitair vertaalonderwijs
}

\begin{abstract}
During the last decades the enhancement of intercultural competence of translators has become one of the main objectives in the training of translators. In Europe, a lot of interesting and diverse theoretical approaches have been developed, offering new insights into the role and importance of this competence in the training of translators. The question put forward in this article is how these insights can be applied in practice, especially in translation colleges.

In order to formulate an answer to this question, I will examine the teaching practice of a few translation teachers in order to find out how this competence is being taught in their teaching practice.
\end{abstract}

\section{Inleiding}

In Europa is de belangstelling voor interculturele competentie sterk toegenomen als gevolg van de culturele en sociale complexiteit inherent bij het Europees burgerschap, waarbij een brede waaier aan talen en culturen betrokken raakte die met elkaar samenleven en op verschillende niveaus met elkaar interageren. Dit veroorzaakte een verschuiving van een etnocentrisch naar een interactief gedragspatroon op basis waarvan relaties tussen verschillende culturen worden opgebouwd. In de vertaaldidactiek heeft dit verschijnsel gezorgd voor een sprong van een kennis- naar een competentiegerichte aanpak, wat bijvoorbeeld naar voren komt in de functionele aanpak waarbij vertalen als een communicatieve handeling wordt beschouwd, en de vertaler optreedt als een expert in interculturele communicatie:

The translator is assumed to be an expert in intercultural communication: s/he analyses the commissioner's aims, expectations and working conditions (Nord 1991) and acts as a cultural consultant. This type of interaction is simulated in the classroom environment. (Vermeer 2011, p. 62) 
In dit artikel zal ik onderzoeken op welke manier (aan de hand van welke werkvormen?) aan drie Europese universiteiten de interculturele competentie van studenten tijdens vertaalcolleges wordt bevorderd. Dit zal ik doen aan de hand van een literatuuronderzoek, verricht op basis van het model van Alice van Kalsbeek voor de bevordering van interculturele competentie in het vreemdetaalonderwijs (Van Kalsbeek 2003, pp. 61-102), waarin elementen zullen worden geïntegreerd van de theorieën van enerzijds Christiane Nord, voorstander van de functionalistische benadering binnen de vertaalwetenschap, en anderzijds van Claire Kramsch die de dialogische pedagogiek vooropstelt voor geïntegreerd taal- en cultuuronderwijs (Van Kalsbeek 2003, p. 98).

In wat nu volgt zal ik eerst de begrippen interculturele competentie en vertaalcompetentie (en haar componenten) definiëren en nagaan hoe ze zich tegenover elkaar kunnen verhouden. Daarna zal ik het theoretische kader van dit onderzoek uiteenzetten, waarbij ik bondig zal ingaan op de functionalistische benadering binnen de vertaalwetenschap (als een van de zeven mogelijke benaderingen), circulair vertaalmodel van Nord en het van Kalsbeek-model waarin elementen van Nord's vertaalmodel zullen worden geïntegreerd om het van Kalsbeek-Nord model te vormen. Daarna volgt de analyse zelf waarin ik op basis van het van Kalsbeek-Nordmodel de werkmethoden aan drie universiteiten zal analyseren en nagaan op welke manier ze concreet bijdragen tot de ontwikkeling van de interculturele competentie van de leerders. Tot slot zal ik, in de context van dit onderzoek naar de bevordering van de interculturele competentie van leerders tijdens vertaalcolleges, in een conclusie nagaan wat de didactische voordelen zijn van de hantering van het model bij het definiëren en uitwerken van werkmethodes.

\section{Interculturele competentie}

In de Delphi Study ${ }^{l}$ wordt interculturele competentie in de hoogst gerangschikte definitie door Darla K. Deardorff als volgt omschreven:

The ability to communicate effectively and appropriately in intercultural situations based on one's intercultural knowledge, skills and attitudes. (Deardorff 2004, p. 194)

Uit Deardorff's definitie kunnen we opmaken dat kennis, competenties en houdingen garant staan voor een doeltreffende en adequate communicatie in interculturele situaties, en dus ook in een vertaling die in de context van de functionele benadering als een interculturele communicatieve handeling wordt beschouwd.

${ }^{1}$ De Delphi Study is een studie die in 2004 werd gerealiseerd door Darla K. Deadorff met als doel het begrip interculturele competentie te definiëren. Hiervoor werden 23 vooraanstaande experts in interculturele communicatie bevraagd, waaronder Michael Byram, Janet Bennett en Guo-Ming Chen Deardorff (2004: 181). 


\section{Vertaalcompetentie en componenten}

Volgens Antony Pym zijn de definities van vertaalcompetentie uiterst heterogeen (Pym 2003, p. 482). Enerzijds zijn er academici die het bestaan ervan volledig ontkennen zoals bijvoorbeeld Wolfram Wilss:

(...) translational competence as a uniform qualification for translational work is, to all intents and purposes, nonexistent and probably also nondefinable" (Wilss 1976, p. 119).

Anderzijds treffen we geleerden aan die de vertaalcompetentie als een vage hypercompetentie beschouwen die een waaier aan onderdelen bevat. Tussen deze twee extreme standpunten, kunnen we een aantal trends identificeren. In een van die trends wordt geopteerd voor een multicomponentiële en interdisciplinaire benadering van de vertaalcompetentie waar ook culturele, technologische en professionele aspecten deel van uitmaken. Dit model met een eindeloos aantal onderdelen wordt bekritiseerd door Pym die beweert dat het uitsluitend door institutionele belangen wordt gedreven en het niet in staat is om gelijke tred te houden met het hoge tempo van de veranderingen in de technologische en professionele veranderingen (Pym 2003, p. 482). Hij stelt de zogenaamde mininalist approach voor en definieert de vertaalcompetentie als de vaardigheid om voor een gegeven brontekst meer dan een mogelijke doeltekst te genereren en die gepaard gaat met het vermogen om uit deze reeks één bruikbare doeltekst te selecteren. In zijn visie wordt het belang benadrukt van de interactie als een fundamenteel onderdeel van de vertaalcompetentie.

Uit de vele modellen die er bestaan voor de omschrijving van de vertaalcompetentie die geconstrueerd zijn op basis van wetenschappelijke bevindingen van academici en als blauwdruk gebruikt worden bij het ontwerpen van vertaalcursussen, selecteerde ik het multicomponentieel model van de PACTE-onderzoeksgroep (Process of Acquisition of Translation Competence and Evaluation). Ik opteerde voor dit model omdat we hierin te maken hebben met een dynamische kijk op de vertaalcompetentie: afhankelijk van de context, kan een bepaalde subcompetentie een min of meer centrale plaats innemen. Deze kijk op vertaalcompetentie houdt ook in dat de vertaalcompetentie uitsluitend kan worden verworven als alle onderliggende competenties geactiveerd worden.

Het PACTE-model bestaat uit vijf subcompetenties en een reeks psycho-fysiologische mechanismen (PACTE 2003, p. 58). Deze subcompetenties zijn:

(1) de tweetaligheidssubcompetentie (bilingual sub-competence): deze subcompetentie houdt hoofdzakelijk verband met de procedurele kennis verreist voor de communicatie in twee talen. Het omvat pragmatische, sociolinguïstische, grammaticale en lexicale kennis;

(2) de extra-linguïsitische subcompetentie (extra-linguistic sub-competence): deze competentie heeft betrekking op impliciete en expliciete wereldkennis en 
de kennis van één of meerdere specialisatiedomeinen. Ze omvat: (1) biculturele kennis (d.i. kennis van de bron- en doeltaalcultuur); (2) encyclopedische kennis (of algemene wereldkennis); (3) vakkennis (d.i. kennis van een of meerdere specialisatiedomeinen);

(3) de 'vertaalkennis-subcompetentie' (knowledge about translation subcompetence): deze competentie verwijst hoofdzakelijk naar de impliciete en expliciete kennis over de rol van vertalen en houdt verband met de kennis van de specifieke aspecten van het vertalersberoep.

(4) de instrumentele subcompetentie (instrumental sub-competence): deze competentie houdt verband met de procedurele kennis m.b.t. het gebruik van bronnen en informatie- en communicatietechnologieën die tijdens het vertalen worden toegepast zoals allerhande soorten woordenboeken, encyclopedieën, grammatica's, stijlboeken, parallelle teksten, elektronische corpora, zoekmotoren, etc.;

(5) de strategische subcompetentie (strategic sub-competence): deze subvaardigheid verwijst naar de procedurele kennis die vereist is om de doeltreffendheid van het vertaalproces te garanderen, en om eventuele vertaalproblemen op te lossen. Omdat deze subcompetentie een centrale rol vervult in het vertaalproces en er toezicht op uitoefent, beïnvloedt zij op aanzienlijke wijze alle andere subcompetenties en creëert zij er banden tussen. Dit komt goed tot uiting in figuur 1 die een schematische voorstelling is van het PACTE-model van de vertaalcompetentie uit $2003^{2}$ (PACTE 2005, p. 620).

Het model biedt tot slot ook ruimte voor de psycho-fysiologische componenten (psycho-physiological components) die verband houden met verschillende types van cognitieve- en houdingscomponenten en psychomotorische mechanismen. Zij omvatten: (1) cognitieve componenten zoals geheugen, perceptie, aandacht en emoties, (2) houdingsaspecten zoals intellectuele nieuwsgierigheid, doorzettingsvermogen, nauwkeurigheid, kritische geest, kennis van en vertrouwen in eigen capaciteiten, het vermogen om eigen capaciteiten te meten, motivatie, etc. en (3) vaardigheden zoals creativiteit, logisch redeneren, analyse- en synthesevermogen, enz.

Het PACTE-model verwijst niet expliciet naar de term interculturele competentie, maar naar een extra linguistic competence. Toch kunnen we vaststellen dat de inhoud ervan overeen komt met die van de component die in Michael Byram's model voor interculturele competentie (Figuur 2) savoirs wordt genoemd, en die ook louter verband houdt met cognitieve kennis. Vermoed wordt dat de extralinguistic subcomptence de naam interculturele competentie niet draagt, omdat

2 Het model voor de vertaalcompetentie (TC model) van de onderzoeksgroep PACTE werd voor het eerst gepresenteerd in 1998 en later in 1998, 2000 en 2001(PACTE 1998a, 1998b, 2000, 2001). In 2003 werd het model herzien in het licht van de resultaten van een onderzoek verricht in 2000 (PACTE 2005, p. 610). 


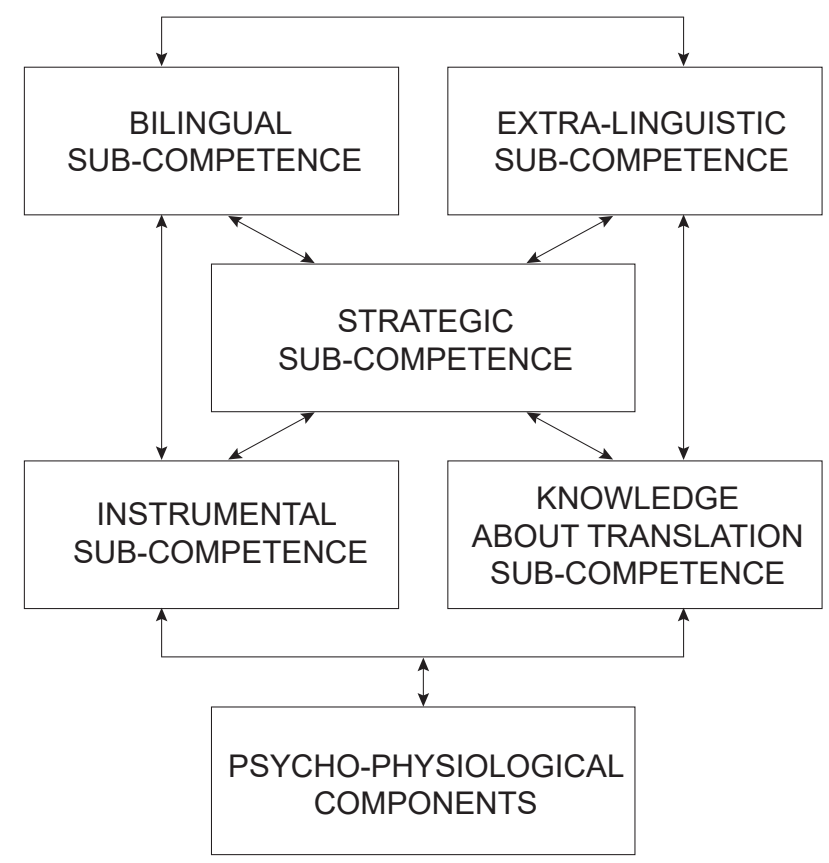

Figuur 1: model vertaalcompetentie (PACTE 2005, p. 610)

interculturele competentie óók verband houdt met aspecten van gedrag en gevoel. Die worden door Byram geclassificeerd onder (1) de savoir apprendre/faire (= de vaardigheid in het ontdekken van elementen van een andere cultuur en daarop te reageren), (2) het savoir être (= de vaardigheid om een open en nieuwsgierige houding aan te nemen ten aanzien van andere culturen) en (3) het savoir $s$ 'engager (= het vermogen om kritisch te kijken naar verhoudingen, praktijken en producten, zowel in eigen land als in vreemde culturen). Die savoirs zijn gewoonlijk moeilijker aan te leren. Bijgevolg ontwikkelde Alice van Kalsbeek voor het vreemdetaalonderwijs een model waarin ze Michael Byram's concepten (die we ook terugvinden in het PACTE-model) integreert. Ik besloot het toe te passen voor het vertaalonderwijs, het aan te vullen met elementen uit de theorie van Christiane Nord (zie hieronder in punt 3.1.) en het te hanteren als analysemodel in dit onderzoek. Aan de grondslag van haar model vinden we verder ook nog drie kernbegrippen Openness, Knowledge, Adaptibility terug die door Byram en Holliday gehanteerd worden om de basis van interculturele competentie te omschrijven. Daar komt nog een vierde kernbegrip bij, namelijk de Critical Awareness of het kritische bewustzijn (van Kalsbeek 2008). 


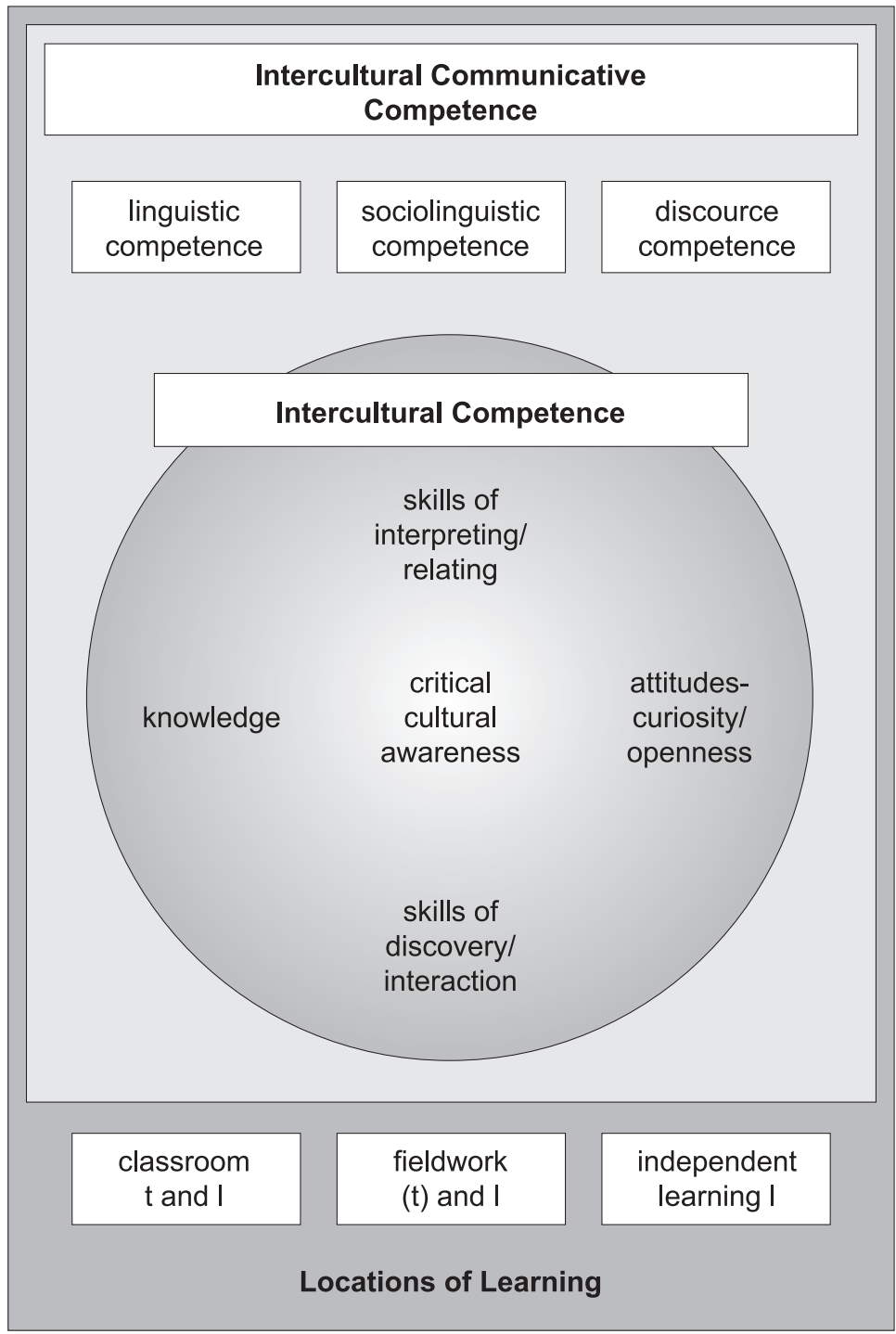

Figuur 2: Byram's (1997) model voor Interculturele Communicatieve Competentie, die zowel de communicatieve als de interculturele competentie omvat (Byram, 2009, p. 323)

$\mathrm{Nu}$ we de begrippen vertaalcompetentie en interculturele competentie hebben gedefinieerd, kunnen we ons afvragen hoe beide begrippen zich tegenover elkaar kunnen verhouden. Er zijn verschillende mogelijkheden. Enerzijds kunnen we ervan uitgaan dat er geen hiërarchisch verband bestaat tussen beide competenties en dat ze zich beide op hetzelfde niveau bevinden. Anderzijds kan worden verondersteld dat de vertaalcompetentie bestaat uit een reeks van subcompetenties 
waaronder de interculturele competentie. Deze oplossing verwijst naar de in punt 3 genoemde multicomponentiële en interdisciplinaire benadering van de vertaalcompetentie die onder meer door de PACTE-onderzoeksgroep (2003) is voorgesteld. Een derde en laatste mogelijke oplossing is een zuiver theoretische, waarbij de vertaalcompetentie een onderdeel is van de interculturele competentie die als overkoepelende competentie fungeert.

In de context van dit onderzoek lijkt de tweede configuratie de meest geschikte, wat erop neerkomt dat de vertaalcompetentie uitsluitend kan worden verworven als alle onderliggende competenties of de competenties waaruit deze is samengesteld, geactiveerd worden. Dit betekent dat als er een leemte ontstaat in één van deze onderliggende of subcompetenties, de vertaalcompetentie gebrekkig zal zijn. Afhankelijk van de situatie kan een bepaalde subcompetentie een min of meer centrale plaats innemen. Bij wijze van voorbeeld: de interculturele competentie zal een centrale rol vervullen bij het vertalen van een tekst over de Nederlandse en Vlaamse nationale identiteit. Deze competentie zal weliswaar ook van belang zijn bij het vertalen van een wetenschappelijke tekst over bijvoorbeeld de zwaartekracht, maar de rol ervan zal dan minder doorslaggevend zijn.

\section{De skopostheorie}

Volgens Calzada Perez (2005, pp. 2-3) kunnen we zeven trends opmerken in de vertaalstudie, elk met een andere focus met name:

(1) een focus op (meestal 'discrete' eenheden van) talen (bijv. in de vertaaltheorie van Jakobson, Vinay en Darbelnet);

(2) een focus op de communicatieve aard van de teksten (bijv. bij Neubert en Shreve House 1981, 1997 en Hatim en Mason);

(3) een focus op communicatieve doelstellingen inherent aan teksten (bijv. bij Reiss; Vermeer en Nord);

(4) een focus op de link tussen vertaling en doelculturen (bijv. bij Even-Zohar; Toury en Lefevere);

(5) een focus op de 'nieuwe vertaalethiek' (bijv. bij Bassnett enLefevere, Venuti);

(6) een focus op de vertaler als een rationeel en emotioneel wezen (bijv. bij Seleskovitch, Krings, Gutt);

(7) een focus op de vertaling van corpora (bijv. bij Baker, Kenny en Laviosa).

Rekening houdend met het feit dat mijn onderzoek verband houdt met het opsporen van activiteiten die in vertaalcolleges de interculturele competentie van studenten bevorderen, lijkt een zoektocht naar werkmethoden met de focus op communicatieve doelstellingen inherent aan teksten (cfr.3) ons de meest voor de hand liggende. Deze focus maakt deel uit van de functionalistische vertaalbe- 
schouwing waar vertaling in de eerste plaats beschouwd wordt als een handeling van interculturele communicatie (act of intercultural communication).

Een belangrijke vertegenwoordiger van de functionele vertaalbeschouwing staat bekend onder de naam skopostheorie die werd ontwikkeld door Katharina Reiss en Hans J. Vermeer (1984). Zij beschouwen vertaling als een translatorisch handelen dat gebaseerd is op een brontekst en definiëren de skopos als de opzet van dit handelen, het doel dat de tekst moet vervullen in de doelcontext. In de praktijk komt dit erop neer dat vertalers (en in ons geval de studenten) eerst de functionalistische vraag wie zegt wat door middel van welk kanaal aan wie en met welk effect? zullen moeten beantwoorden voordat ze besluiten hoe ze een specifieke brontekst in een andere taal en cultuur zullen weergeven.

Eén van de pluspunten van deze theorie is de erkenning van de rol van de opdrachtgever bij het definiëren van de vertaalopdracht en het feit dat het vertaalproces wordt gezien als een beslissingsproces, waarbij de criteria voor de goede beslissing worden aangereikt door de skopos of het concrete doel van de vertaling.

\section{Het circulair vertaalmodel van Christiane Nord}

Binnenin het functionalistische model zorgde Christiane Nord voor een praktische 'procedure van aanpak' om te verhinderen dat studenten 'in het luchtledige' vertalen en om te bevorderen dat ze de juiste vragen stellen met het oog op het vertaaldoel. In tegenstelling tot de tweeledige (begrijpen, uitdrukken) of drieledige (begrijpen, 'deverbaliseren', uitdrukken), stelt ze een circulair vertaalmodel voor (Nord, 1991: 34-35): bij elke stap die de vertaler neemt moet hij terugblikken op de factoren die aan het licht kwamen bij de analyse van de brontekst (zie hierna onder 'stap 2'), en de gevolgen ervan voor de potentiële doeltekst (Nord, 1991: 35 ). Hij moet zich voortdurend heen en weer bewegen om de meest geschikte oplossingen te kiezen, zonder ook maar één van deze factoren uit het oog te verliezen. Dit komt goed naar voren in de schematische afbeelding van Nord's circulair vertaalprocedé (cfr. figuur 3):

De eerste stap in het model is de vraag naar de functie of bedoeling van de doeltekst (= analysis of TT skopos). In de tweede stap wordt een analyse van de brontekst gemaakt, eerst van de tekstexterne factoren (die te maken hebben met tijd, plaats en situatie waarin de tekst tot stand kwam) en daarna van de tekstinterne factoren (o.a. thematiek, inhoud, tekststructurering, non-verbale elementen, woordgebruik en syntactische structuur, taalfuncties, stijl en 'toon'). In de derde stap wordt beslist over het type vertaling dat nodig is (welke elementen uit de brontekst kunnen gehandhaafd worden? Welke elementen moeten hoe worden gewijzigd?) wat afhangt van het vertaaldoel zoals in de vertaalopdracht is vervat. In de vierde fase de vertaler aan de slag met het structureren en redigeren. Hier komen woordenboeken, naslagwerken, vertaalgeheugens en andere tools voor 


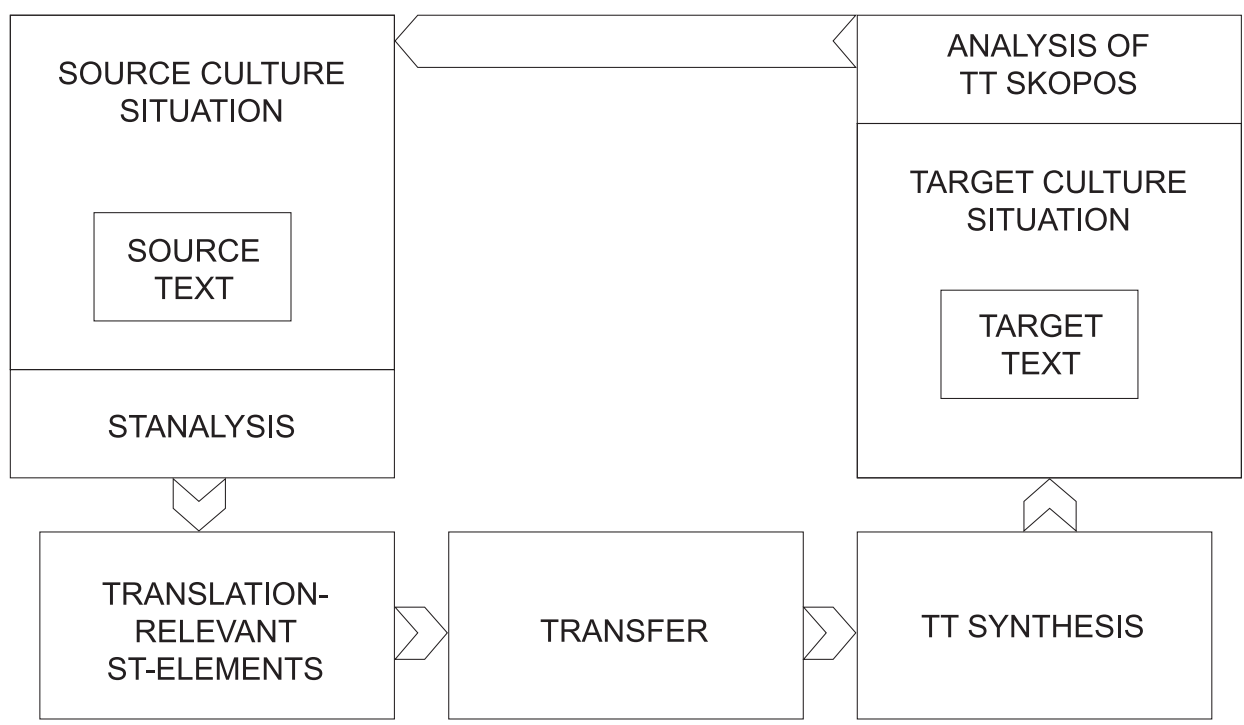

Figuur 3: circulair vertaalmodel van Nord (1991: 34)

vertaalondersteuning op de proppen. Tijdens het vertaalproces zal de vertaler een beroep doen op bepaalde vertaalstrategieën, waarbij volgens Nord niet de brontekst, maar de functie die de vertaling in de ontvangende cultuur moet vervullen, bepalend is voor de keuze van de vertaalstrategie. Nord's model kan worden toegepast op alle tekstsoorten, inclusief literaire.

De aanpak van Nord kan, althans voor wat betreft de vraagstelling over en omtrent de vertaling, opmerkelijk goed worden ingebouwd in het didactische model dat door Alice Van Kalsbeek werd ontworpen om de interculturele communicatieve competentie van vreemdetaalleerders te bevorderen.

\section{Het van Kalsbeek-model}

Zoals reeds eerder aangestipt in de inleiding van dit artikel, ontwikkelde Alice van Kalsbeek (2003) een model voor de bevordering van de interculturele competentie in het vreemdetaalonderwijs. Aan de grondslag van haar model vinden we de drie kernbegrippen Openness, Knowledge, Adaptibility terug die Byram (e.a. 1997) hanteren om de basis van interculturele competentie te omschrijven. Daar komt nog een vierde kernbegrip bij, met name de Critical Awareness of het kritische bewustzijn (Van Kalsbeek, 2008).

Van Kalsbeek (2003, p. 91) stelt vast dat in de didactiek van een geïntegreerd taal- en cultuuronderwijs drie begrippen regelmatig naar voren komen: perspectief, context en dialoog. Deze drie begrippen verwijzen naar werkvormen 
die bijdragen tot de culturele bewustwording, de kennis over andere culturen (de doelcultuur), de ontwikkeling van interculturele vaardigheden. Ze worden door haar als een soort van geleiders beschouwd om interculturele competentie te verwerven. Bij de integratie van al deze fundamentele begrippen, komt van Kalsbeek (2008) tot het volgende schema:

\begin{tabular}{|l|l|l|l|}
\hline General & Openness & $\rightarrow$ & Attitude \\
\hline & Knowledge & $\rightarrow$ & Knowledge \\
\hline & Flexibility & $\rightarrow$ & Skills \\
\hline Profession oriented & Perspective & $\rightarrow$ & Attitude \\
\hline & Context & $\rightarrow$ & Knowledge \\
\hline & Dialogue & $\rightarrow$ & Skills \\
\hline
\end{tabular}

Figuur 4: van Kalsbeek-model: schematische voorstelling didactiek van een geïntegreerd (ver)taal- en cultuuronderwijs (Van Kalsbeek 2010)

Volgens van Kalsbeek (2008, p. 3) verwijzen de algemene competenties onder meer naar Byram's (1997) savoirs die elke interculturele communicator nodig heeft om te kunnen functioneren als een intercultural individual (een intercultureel competente enkeling). Ze onderscheidt deze competenties van de beroepsgerelateerde competenties die een vreemdetaaldocent - en in ons geval een vertaaldocent - moet bezitten om deze (via bepaalde werkmethodes) te onderrichten aan zijn/haar studenten, zodat zij later als vertalers kunnen functioneren als cultural being (cultureel wezen) of, om het met de woorden van de functionalist Hans J. Vermeer te zeggen, als experts in interculturele communicatie (Vermeer 1998, p. 63). In de context van het beroep van vertaler houdt dit verband met competenties die zich specifiek richten op het werk als vertaler en die verband houden met zowel kennis, vaardigheden als gedrag.

De geleider perspectief houdt onder meer verband met de bewustwording van de eigen attitude ten opzichte van eigen en andere culturen. Elk van ons heeft algemene structuren van taal en taalelementen in zijn hoofd die in belangrijke mate onze waarneming bepalen. Deze algemene structuren worden 'frames' of 'schemata' genoemd. In het vreemdetaalonderwijs spelen die preconcepties een rol. Voordat de leerders een taak uitvoeren, is het belangrijk om te ontdekken wat hun preconcepties zijn en waar die moeten worden bijgesteld. In dit soort onderwijs zijn werkvormen om dit te doen bijvoorbeeld het vragen naar voorkennis, het werken met woordvelden, het stellen van vragen bij foto's, het bepalen van het perspectief van een tekst (van Kalsbeek 2003, p. 91). Ook bij het vertalen is het belangrijk dat leerders zich bewust worden van dit soort preconcepties, vooral met het oog op het innemen van het (cultureel) perspectief van de doelgroep van waaruit zij een tekst zullen vertalen en adequate vertaalstrategieën zullen toepassen. 
De geleider context brengt van Kalsbeek in verband met de kennis van de doelcultuur die leerders nodig hebben. Voorbeelden van werkvormen die bij het aanleren van een vreemde taal kunnen worden toegepast, zijn zoekopdrachten op internet, achtergrondgeluiden bij een video, verandering van context (van Kalsbeek 2003, p. 91).

Tot slot stelt van Kalsbeek de geleider dialoog in verband met werkmethodes die kunnen worden gecreëerd met het oog op de ontwikkeling van de interculturele vaardigheden van leerders. Als uitgangspunt hanteert zij de visie op taal en cultuur van Claire Kramsch waarin cultuur geen object is dat kan worden onderwezen. Kramsch introduceert de dialogische pedagogiek voor geïntegreerd taalen cultuuronderwijs en stelt groepswerk (pairwork) voorop als methode bij uitstek om inzicht te krijgen in elkaars culturele bagage. Volgens Kramsch kan op die manier de lessituatie worden omgevormd tot een proeftuin van de samenleving.

\section{Het van Kalsbeek-Nord model}

Wanneer we het stappenplan van het circulaire vertaalmodel van Nord integreren in het model van Van Kalsbeek, levert dit ons het volgende schema op:

\begin{tabular}{|l|l|l|l|}
\hline General & Openness & $\rightarrow$ & Attitude \\
\hline & Knowledge & $\rightarrow$ & Knowledge \\
\hline & Flexibility & $\rightarrow$ & Skills \\
\hline Profession oriented & $\begin{array}{l}\text { Perspective } \\
\text { Nord: stap 1 }\end{array}$ & $\rightarrow$ & Attitude \\
\hline & $\begin{array}{l}\text { Context } \\
\text { Nord: stap 2 }\end{array}$ & $\rightarrow$ & Knowledge \\
\hline & $\begin{array}{l}\text { Dialogue } \\
\text { Nord: stap 3 }\end{array}$ & $\rightarrow$ & Skills \\
\hline
\end{tabular}

Figuur 5: van Kalsbeek Nord-model: schematische voorstelling functionele didactiek voor geïntegreerd vertaal- en intercultuureel communicatief onderwijs

In het van Kalsbeek-Nord model krijgen de geleiders de volgende inhoud en betekenis:

- Perspectief: hier kan worden gedacht aan het ontwikkelen van activiteiten voor het mobiliseren van de voorkennis over de te vertalen tekstsoort en de functie of de bedoeling (= skopos) van de doeltekst in de doelcultuur. Volgens Nord is die vaak impliciet, maar kan die expliciet worden gemaakt in een gedetailleerde vertaalopdracht met informatie over wie de opdrachtgever is, in welk land (streek, stad), op welk tijdstip en in welk medium de vertaling zal verschijnen, wat de aanleiding is voor de publicatie, voor welke doelgroep die bestemd is en welke 
nieuwe taalfuncties de tekst moet bevatten. Dankzij het antwoord op deze vragen kan de vertaler als het ware de positie innemen van de ontvanger met het oog op het kiezen van adequate vertaalstrategieën in stap 3 .

- Context: deze geleider kan in verband worden gebracht met de ontwikkeling van werkmethodes in de lijn van Nord's tweede stap van haar circulaire model waarin de analyse van de brontekst gemaakt wordt, eerst van de tekstexterne factoren (die te maken hebben met tijd, plaats en situatie waarin de tekst tot stand kwam) en daarna van de tekstinterne factoren (o.a. thematiek, inhoud, tekststructurering, non-verbale elementen, woordgebruik en syntactische structuur, taalfuncties, stijl en 'toon'). Hier kan worden gedacht aan activiteiten die ondermeer beogen de kennis van de leerder met betrekking tot een of meerdere specifieke tekstinterne factoren te optimaliseren (bijv. culturele referenties, taalfuncties, tekststructurering). Dit kan bijvoorbeeld bewerkstelligd worden aan de hand van een vergelijking van de situationele en tekstuele eigenschappen van een bepaalde tekstsoort (bijv. een zakelijke brief, een reclametekst, een krantenartikel) in de bron- en doeltekstculturen. Dit type vergelijking gaat veel verder dan de methodes van de contrastieve taalkunde, want het is altijd ingebed in situationele contexten en vergezeld van functionele specificaties. Dergelijke oefeningen bevorderen de tekstuele bevoegdheid en kennis van de leerders voor een aantal teksttypen.

- Dialoog: in de context van de vertaaldidactiek kan deze geleider ook gerelateerd worden aan de dialogische pedagogiek van Kramsch die stelt dat in de dialoog de interactie tussen o.a. (bron)tekst en context en tussen de verschillende interpretaties van een (bron)tekst aan de orde komen (van Kalsbeek 2003, p. 98). Deze pedagogiek kan zich ook tijdens vertaalcolleges realiseren in groepswerk waar studenten, in de lijn van stap 3 van Nord's vertaalmodel, samen de nodige vertaalkeuzes bespreken en maken, vooraleer ze overgaan tot het vertalen van de tekst.

\section{Analyse werkmethoden voor interculturele competentie}

In wat nu volgt zal ik aan de hand van een literatuuronderzoek en met behulp van het van Kalsbeek-Nord-model, de werkmethoden bespreken die worden ingezet ter bevordering van de interculturele competentie in de vertaalcolleges van (1) de Bacheloropleiding aan de KU Leuven campus Brussel, (2) de Masteropleiding aan de afdeling Engelse en Amerikaanse Studies in Brno (Tsjechië) en (3) de Bacheloropleiding aan de Leerstoel Nederlandse Taal en Literatuur van de KUL Johnnes Paulus II universiteit Lublin (Polen).

\subsection{Bachelorpleiding Vertalen - KU Leuven, campus Brussel}

In de Bacheloropleiding 'Vertalen' werken de studenten in het kader van de cursus Traduction de textes culturels aan het vertalen van recensies van het Kunstenfesti- 
valsdesarts (een internationaal festival van de kunsten in heel Brussel). De cursus beoogt hoofdzakelijk de interculturele competentie van studenten te verscherpen (Peeters 2003, p. 258) door middel van communicatieve pedagogische taken die in de optiek van de perspective actionnelle worden uitgevoerd die de Raad van Europa voorstelt voor het vreemdetaalonderwijs, en die het actieve gebruik van een taal beoogt (Peeters 2011, p. 175).

We kunnen ons hierbij afvragen of voor dit type vertaalcolleges de functionele aanpak als theoretisch kader niet beter geschikt is dan de perspective actionnelle, daar we onder de negen doelstellingen van deze vertaalcolleges ondermeer kunnen lezen dat de leerders aan het eind van het semester in staat moeten zijn om een tekst aan te passen of te herschrijven voor een andere doelgroep (Peeters 2011, p. 178), wat volledig in de lijn ligt van de doelstelling van de functionele benadering waar de uitvoering van een vertaaltaak beoogt een doeltekst te creëren die in de doelcultuur kan functioneren.

Hoe worden de drie geleiders in de vertaalcolleges van Bachelorpleiding Vertalen aan de KU Leuven campus Brussel gestimuleerd?

- Perspectief: zoals we hebben gezien is de eerste stap in Nord's model de vraag naar de functie of bedoeling (= skopos) van de doeltekst. Binnen deze vertaalcolleges stelt de docent de leerders in staat om die te herkennen en te begrijpen door middel van een voorafgaande ontmoeting met het hoofd van de afdeling communicatie van het festival, die onder meer het programma en de opzet van het festival presenteert. De studenten worden op die manier en ook daarna aangezet om in tweetallen te reflecteren op het doel en de doelgroep van de vertaling (zie fase 1 van Nord's stappenplan) en om te kiezen voor een passend vertaalperspectief (bron- of doeltaalgeoriënteerd?).

- Context: een van de doelstellingen van deze vertaalcolleges is het verwerven van de nodige vaardigheden en analytische technieken voor de vertaling van verschillende soorten teksten uit het domein cultuur (Peeters 2011, p.178). Wanneer we dit in verband brengen met stap 2 van Nord's vertaalmodel waar het erop neerkomt dat leerders een analyse maken van de tekstexterne en -interne factoren van de brontekst, zien we dat in deze colleges de aandacht vooral uitgaat naar de culturele referenties (die door hun specifieke karakter vaak vertaalproblemen kunnen opleveren). De studenten krijgen hier namelijk de opdracht om in tweetallen dergelijke cultuurgebonden termen en andere eventuele vertaalproblemen in de tekst op te sporen en aan te duiden:

Le professeur leur demande dans une première étape de lire attentivement les critiques à traduire et d'indiquer les références culturelles, tout comme d'autres problemes de traduction éventuels. (Peeters 2011, p. 181)

De notie culturele referentie wordt in de context van deze colleges naar het voorbeeld van Scott-Tennent en González Davies als volgt gedefinieerd:

Any kind of expression (textual, verbal, non-verbal or audiovisual) denoting any material, 
ecological, social, religious or linguistic manifestation that can be attributed to a particular community (geographic, socio-economic, professional, linguistic, religious etc.) and would be admitted as a trait of that community by those who consider themselves to be members of it. (Peeters 2011, p. 189)

- Dialoog: De geleider dialoog wordt in de eerste plaats gestimuleerd doordat groepswerk als methode wordt toegepast om de studenten aan het project te laten werken. In het kader van de colleges krijgen ze bijvoorbeeld de opdracht aan hun medestudenten hun voorstel(len) voor de vertaling (van culturele referenties en andere ontdekte vertaalproblemen) te presenteren, terwijl ze hun vertaalkeuzen verantwoorden. Op die manier worden ze klassikaal aangezet tot reflectie over hoe vertaalproblemen kunnen worden opgelost.

\subsection{Masteropleiding aan de afdeling Engelse en Amerikaanse Studies - Masaryk Universiteit, Faculteit der Letteren, in Brno (Tsjechië)}

De vertaalcursus aan deze afdeling wordt onderverdeeld in drie fasen die afwijken van het traditioneel docentgericht scenario (Kamenická \& Rambousek 2012, p.93):

- In fase 1 (= tekstselectiefase) selecteren de studenten zelf een tekst uit het domein waarin ze het meest ervaring hebben op het gebied van vertalen;

- In fase 2 (= het hoofddeel van de cursus bestaande uit een aantal vertaalsessies) stellen de studenten hun tekst voor in de vorm van een vertaaltaak. Tijdens de vertaalsessies, onder leiding van de studenten, wordt feedback gegeven op de vertalingen van medestudenten. In deze fase hebben we dus te maken met studentcreated content;

In fase 3 (= evaluatie) staat de docent centraal die een cijfer geeft voor twee vertalingen: een eerste voor een vertaling uit het 'preferentiedomein' van de student, en een tweede voor vertaling uit een 'neutraal' domein.

De cursus beoogt om via een aantal methodes de zin voor initiatief en de autonomie van de studenten te stimuleren door ze bijvoorbeeld de rol te laten spelen van opdracht- en feedbackgevers en ze te laten optreden als docenten die tijdens de vertaalsessies discussies leiden die de studenten zullen helpen bij het herformuleren van hun vertaling. (Kamenická \& Rambousek 2012, p.93).

Hoe worden de drie geleiders gestimuleerd in de vertaalcolleges in Brno?

- Perspectief: Deze geleider wordt gestimuleerd door een werkvorm waarbij elke student-docent in fase 1 (=tekstselectiefase) optreedt als opdrachtgever en het doel (=skopos), de doelgroep en het medium waarin de tekst zal verschijnen bepaalt. Dit zet hem/haar en de andere leerders aan om te reflecteren over het profiel van de doeltekst, en om het perspectief van de doelgroep in te nemen. Deze werkmethode ligt in de lijn van de eerste stap van Nord's vertaalmodel (cfr. profiel doeltekst optellen). 
- Context: De studenten vertalen de tekst individueel en sturen hun vertaling naar de student-docent via een moodle-elektronische leeromgeving. Tijdens het vertalen kunnen leerders gebruik maken van ondersteunend materiaal dat ze met de instructie van de student-docent ontvingen (bijv. beeldmateriaal bij de vertaling van een gebruiksaanwijzing). De student-docent selecteert specifieke vertaalproblemen die tijdens de vertaalcolleges worden belicht en besproken. Hij ondersteunt vertaalkeuzes en geeft feedback door het aanvoeren van bewijsmateriaal. Aan de hand van deze methode verwerven de student-docent en de andere leerders analytische en technische vaardigheden en vooral kennis die nodig is voor het vertalen van verschillende tekstsoorten en voor het oplossen van specifieke vertaalproblemen.

- Dialoog: deze geleider wordt gestimuleerd op basis van discussies die de student-docent tijdens de vertaalsessies voert op basis van geleverde feedback op geselecteerde passages uit de tekst. Dankzij deze feedback worden de leerders vaardig in het vertalen van allerhande gespecialiseerde teksten.

\subsection{Bacheloropleiding aan Leerstoel Nederlandse Taal en Literatuur - KUL Johannes Paulus II Lublin (Polen): het JPII-vertaalproject in $\operatorname{spe}^{3}$}

Tijdens het academiejaar 2014-15 heeft een Poolse vereniging van Nederlandse, Poolse en Vlaamse professionele vertalers aan de Leerstoel Nederlandse Taal en Literatuur in Lublin voorgesteld om gratis workshops te verzorgen voor studenten rond de vertaling van gespecialiseerde teksten. De workshops bleken echter niet geschikt te zijn voor bachelorstudenten die meer nut bleken te hebben van het verwerven van een dieper inzicht in de procedure van aanpak. Bijgevolg is de Leerstoel van plan om in de toekomst voor zijn bachelorstudenten een project op te starten rond de vertaling van teksten over culturele onderwerpen. In het project zou de vereniging van vertalers optreden als opdrachtgever die bovendien tijdens thematische workshops professionele feedback zou leveren op vertaaltaken.

Aan de hand van de vertaling van cultuurteksten zouden studenten bewust worden gemaakt van de actoren die betrokken zijn in de vertaalinteractie, van de culturele en communicatieve context waarin een vertaling zich situeert, van de functie die de opdrachtgever van de vertaling verwacht (= de rol die de vertaling in de doelcultuur moet vervullen) e.d.m.. Dergelijke inzichten en kennis zouden hen naderhand in staat stellen om adequate beslissingen te nemen voor concrete vertaalproblemen door het toepassen van de adequate vertaalstrategieën. Dankzij de noodzaak van een sterkere 'culturele contextualisering' die er bestaat bij het verta-

${ }^{3}$ Deze analyse werd gemaakt op basis van een artikel dat binnenkort zal verschijnen in een bundel naar aanleiding van de 10th Brno International Conference of English, American and Canadian Studies. 
len van culturele teksten, waar vertaald wordt van 'context' naar 'context', hoopt de Leerstoel via dit project dat zich concentreert rond de training in het vertalen van dit soort teksten, de interculturele competentie van zijn leerders te bevorderen.

Het project zal dus focussen op de vertaling van teksten over culturele onderwerpen zoals instellingen van een land, cultuurgeschiedenis, zeden en gewoonten, tradities, beeldende kunst, muziek, media, literatuur. Dergelijke teksten bevatten heel wat culturele referenties. Volgens Gonzalez Davies \& Scott-Tennent (2005, p. 166) wordt in het vertaalonderwijs te weinig aandacht besteed aan deze problematiek. Om tegemoet te komen aan deze lacune, zal in het vertaalproject aandacht worden besteed aan dit aspect door te werken rond de vertaling van culturele referenties.

Hoe zouden de drie geleiders gestimuleerd in het project worden ingezet?

- Perspectief: De geleider perspectief wordt gestimuleerd via een ontmoeting met de vertegenwoordiger of met een lid van de vereniging van professionele vertalers. Die geeft de studenten een vertaaltaak uit de beroepspraktijk, samen met een vertaalinstructie die informatie bevat over de skopos, de doelgroep, het medium waarin de vertaling zal verschijnen (en hoeveel tijd ze hebben om de vertaling te maken). Die gegevens stellen hen in staat om het profiel van de doeltekst te bepalen (= stap 1 van Nord's vertaalmodel) op basis waarvan ze zouden kiezen voor een bron- of doelcultuur georiënteerde vertaling.

- Context: Deze geleider wordt geactiveerd doordat de studenten, na een grondige lectuur van de brontekst, als eerste opdracht zouden krijgen om de culturele referenties en eventuele vertaalproblemen in de tekst op te sporen $(=\operatorname{stap} 2$ van Nord's vertaalmodel waarin aandacht wordt besteed aan het opstellen van het profiel van de brontekst). Naderhand vertalen de leerders in tweetallen de cultuurgebonden termen (met behulp van woordenboeken, naslagwerken en informatie in bibliotheken en op het internet) en formuleren oplossingen voor specifieke vertaalproblemen. Daarbij gaan ze ook op zoek naar bewijsmateriaal om hun vertaalkeuzen en - oplossingen te verantwoorden (bijv. aan de hand van vergelijkingen met soortgelijke teksten en hun vertaling). Op die manier verrijken ze hun inzicht in de vertaaltechnieken die kunnen worden toegepast bij het vertalen van verschillende teksttypen uit het culturele domein die bestemd zijn voor een concreet medium.

- Dialoog: Deze geleider wordt gestimuleerd doordat de studenten in groep werken rond de vertaling van de tekst en van de culturele referenties die hij bevat en elk tweetal zijn vertaalkeuzes en oplossingen voor vertaalproblemen aan de groep presenteert en beargumenteert. Op basis van deze discussies bespreken en maken de studenten (in tweetallen) de nodige vertaalkeuzes en gaan ze over tot de vertaling van de volledige tekst (= stap 3 van Nord's vertaalmodel). De vertalingen worden tot slot aan de opdrachtgever (= de vertalersvereniging) bezorgd, die tijdens een workshops in de vorm van een discussie feedback levert op geselecteerde tekstfragmenten. De studenten worden uitgenodigd om op actieve wijze deel te nemen aan de discussies en om zich hierbij onder meer te beroepen op de 
door hen verzamelde informatie (bewijsmateriaal) tijdens de aan de workshop voorafgaande vertaalcolleges.

\section{Conclusie}

Uit deze analyse blijkt dat 'de fusie' van het model van Van Kalsbeek met dat van Nord een handig instrument is voor het opsporen van werkmethodes die tijdens vertaalcolleges de interculturele competentie van leerders bevorderen. Dit komt doordat het model van Van Kalsbeek specifiek gericht is op werkmethodes voor de bevordering van deze competentie van leerders, terwijl dat van Nord op werkmethodes voor de transfer van een tekst van bron- naar doelcultuur. Doordat in beide modellen het interculturele aspect centraal staat, kunnen we via de integratie van beide modellen komen tot een nieuw en gedetailleerder model voor de analyse van didactische methodes, gericht op de bevordering van deze competentie bij het transfereren of herschrijven van teksten van bron- naar doelcultuur. Bovendien kan het als instrument worden ingezet voor het doelbewuster creëren van werkmethodes die dit beogen via het vertalen van teksten. Handig hierbij is dat er hiervoor gebruik kan worden gemaakt van drie geleiders:

- Voor de geleider perspectief kunnen werkmethodes worden ontwikkeld die de studenten aanzetten tot het innemen van een adequaat vertaalperspectief. Hier zal vooral aandacht moeten worden besteed aan het ontwikkelen van opdrachten die studenten daadwerkelijk helpen bij opstellen van het profiel van de doeltekst, zodat ze in staat worden gesteld om het perspectief van een nieuwe initiator of zender van de tekst aan te nemen die de compatibiliteit tot stand moet brengen tussen brontekstintentie en doeltekstfunctie.

Uit deze analyse in gebleken dat een van de meest effectieve methodes erin bestaat om de studenten, bij de vertaalopdracht, een op voorhand goed doordachte en degelijk uitgewerkte taakinstructie te geven (die zo mogelijk door een (fictieve) opdrachtgever wordt aangeleverd) die hen in staat stelt om in functie van het ingenomen vertaalperspectief de nodige vertaalkeuzen te maken.

- Voor het stimuleren van de geleider context kunnen werkmethodes ontwikkeld worden die de analyse beogen van specifieke elementen van de brontekst. Dit kan slaan op tekstexterne en -interne factoren. Uit deze analyse is gebleken dat docenten er bijvoorbeeld voor kunnen kiezen om aandacht te besteden aan een bijzonder aspect van de te vertalen tekst, zoals cultuurgebonden termen in het voorbeeld van universiteit van Leuven en Lublin.

- Voor de geleider dialoog kunnen tot slot werkmethodes worden ontwikkeld die de studenten aanzetten tot het nemen van doordachte beslissingen omtrent het type vertaling dat nodig is en de vertaalstrategie die dient te worden toegepast. Deze vaardigheid kan worden aangeleerd en bevorderd via discussies met een fictieve opdrachtgever (zoals in het geval van de universiteit van Brno), met 
professionele en beëdigde vertalers (zoals aan de universiteit van Lublin) en met medestudenten.

Kortom, het model leent zich uitstekend voor het ontwikkelen van werkmethodes doordat er doeltreffender kan worden gezocht naar manieren om leerders te doen nadenken over de functie die een vertaling in de ontvangende cultuur moet vervullen. Dit gebeurt in een professionele en semi-professionele context waarin hun motivatie wordt gestimuleerd, waarin ze worden aangezet tot het vergaren van juiste informatie, tot het nemen van beslissingen en tot het oplossen van problemen in een concrete context zodat ze uitstekende interculturele mediatoren worden in de vertaalwereld.

\section{Bibliografie}

Byram, M.G. Zarate \& G. Neuner (1997). Sociological competence in language learning and teaching. Strasbourg: Council of Europe.

Byram, M. (2009). The Intercultural Speaker and the Pedagogy of Foreign Langauge Education. In D. K. Deardorff (Ed.), The SAGE Handbook of Intercultural Competence. Thousand Oaks, CA: Sage. 321-332.

Calzada Pérez, M. (2005). Applying Translation Theory in Teaching. New Voices in Translation Studies 1, 1-11.

Deardorff, D.K.(2006). Identification and assessment of intercultural competence as a student outcome of internationalization of higher education in the United States. Journal of Studies in International Education, 10(3), 241-266

Gonzalez Davies, M., Scott-Tennent C. (2005). A Problem-Solving and Student-Centred Approach to the Translation of Cultural References. Meta, 50 (1), 160-179.

Kalsbeek, A. van. (2003). Taal en cultuur of cultuur en taal?. Cultuur in taal. Interculturele vaardigheden voor docenten Nederlands aan anderstaligen. C. van Baalen, L. Beheydt \& A. van Kalsbeek. Utrecht: ncb. 61-102.

Kalsbeek, A, van. (2008). Intercultural competences for Foreign Language Teachers. http://intt.uva. $\mathrm{nl} /$ binaries/content/assets/subsites/institute-for-dutch-as-a-second-language/map-1/interculturele-competenties-in-het-nt2-onderwijs-auteurskwaliteiten-of-docentvaardigheden.pdf, geraadpleegd in augustus 2015 .

Kalsbeek, A., van. (2010). Cultuur in het onderwijs Nederlands als tweede taal: auteurskwaliteiten of docentvaardigheden?. Vakwerk 6. VU Reprografie: Amsterdam.

Kamenicka R. \& Rambousek J. (2012). Activating Student Autonomy in Translation Training: InClass and Online. Teaching Translation and Interpreting Skills in the $21^{\text {st }}$ Century. Palacký University: Olomouc. 93-103.

Nord, C. (1991). Text analysis in translation: theory, methodology, and didactic application of a model for translation-oriented text analysis. NY: Rodopi. Amsterdam/NewYork.

PACTE. (2003). Building a Translation Competence Model. In: Alves, F. (ed.). Triangulating Translation: Perspectives in Process Oriented Research, John Benjamins Publishing Co, Amsterdam, 43-66.

PACTE group. (2005). Investigating Translation Competence: Conceptual and Methodological Issues. Meta, 50 (2), 609-619. 
Peeters, I. (2003). Comment optimiser la compétence (inter)culturelle des étudiants en traduction: un projet authentique prometteur. Babel. Revue Internationale de Traduction / International Journal of Translation, vol:59 issue:3 Amsterdam: John Benjamins Publishing Co., 257-273.

Pym, A. (2003). Redefining Translation Competence in an Electronic Age. In Defence of a Minimalist Approach. Meta, 48 (4), 481-497.

Reiss, K. \& Vermeer, H.J. (1984). Grundleggung einer allgemeinen Translationtheorie. Tubingen: Max Niemeyer Verlag.

Vandeweghe, W. (2005). Duoteksten: inleiding tot vertaling en vertaalstudie, Academie Press, 217

Vermeer, H.. J. (1998). Didactics of translation. The Routledge Encyclopedia of Translation Studies. Mona Baker (ed.). London/New York: Routledge. 60-62. 